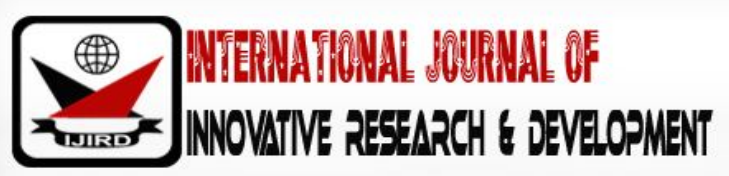

ISSN 2278 - 0211 (Online)

\section{Misuse of Instructional Time and Its Effect on Students' Academic Achievement in Four Public Senior High Schools in the Ashanti Mampong Municipality of Ghana}

\begin{tabular}{|c|} 
Benedict Osei-Owusu \\
Senior Lecturer, Department of Interdisciplinary Studies, University of Education, Winneba, Ghana \\
Eric Twum Ampofo \\
Lecturer, Department of Interdisciplinary Studies, University of Education, Winneba, Ghana \\
Robert Ampomah \\
Kecturer, Department of Interdisciplinary Studies, University of Education, Winneba, Ghana \\
Kwadwo Oteng Akyina \\
Lecturer, Department of Interdisciplinary Studies, University of Education, Winneba, Ghana \\
Esther Osei-Ow usu \\
Assistant Headmistress. Amaniampono Senior Hiah School, Ghana
\end{tabular}

\begin{abstract}
:
Time is an intangible resource and one of the major features of human development. Thus, instructional time should be used efficiently to enhance both the teaching and learning processes. This study sought to ascertain the association between instructional time misuse and students' academic achievement. The study was a descriptive survey and the views of 326 respondents comprising 322 teachers, 3 headmasters and 1 headmistress from the four Senior High Schools in the Ashanti Mampong municipality of Ghana were sought using a self-developed questionnaire. The study revealed that misuse of instructional time has an adverse effect on the academic performance of students. Also, the findings of the study established that where there are high prevalence rate maternity leave, sick leave, absenteeism and lateness maximum usage of instructional time is hindered. Again, the study found a negative relationship between misuse of instructional time and students' academic achievement hence we failed to reject the hypothesis that guided the study. Based on the research findings, it is recommended that the Government, the Ministry of Education and stakeholders in education should ensure the efficient and effective usage of instructional time at the Senior High Schools to be specific. Also, headmasters/ headmistresses should be exposed to appropriate management style and leadership technique to see to the judicious utilization of instructional time.
\end{abstract}

Keywords: Instructional time, management techniques, students' academic achievement

\section{Introduction}

A school like any other organization has well defined goals and objectives to achieve. The primary objective of every school is to provide quality education to individuals. For any country to develop its human resource base to a formidable degree, that country needs to put in place necessary policy, structures and procedures that would ensure that its human capital is well developed. Schools are built to ensure that the requisite academic skills and artistic training will be given to individuals. It is against this background that the Ministry of Education (MoE) through the Ghana Education Service (GES) has through their policy and direction communicated in no uncertain terms why heads of schools, teachers and students make optimum use of instructional time. In Ghana, Senior High School (SHS) has specific instructional time to follow. The time-table is structured to ensure that classes begin at 8: 00am and ends at 2:00pm each school day, thus Monday to Friday. Each period covers forty (40) minutes and there are eight period in each school day. Within this regulated time, provisions are made to cater for assembly and break periods. In accordance to the GES regulations, a subject tutor is suppose to teach for a minimum of twenty-four (24) periods per week and a maximum of thirty-six (36) per periods. On average, every tutor has free periods of four within which he or she can prepare his or her less plan, mark and record students' exercises and also work on continuous 
assessment records of students. Indeed, management of time is the core business of all teaching activities which includes how the day is organized, the organization of the classroom and recording of students' marks.

According to Tamakloe, Atta and Amedahe (2011), every aspect of instructional programme of a school depends on the effective management of students in the classroom. There is therefore, a need for co-operation between all members of the school for successful and effective teaching and learning to take place. Time is a very important resource which has to be managed well if we want to accomplish our objective. Hindle (2009) opined that "time is costly; it is a sobering exercise to calculate exactly how much one's time costs and then realize how much of it is not being spent effectively" (p. 8). In Ghanaian schools, activities are programmed for both curricular and co-curricular activities. A plan of action is then drawn to cover a whole year. This pre-supposes that any instructional time wasted or under-utilized will result in a limited coverage of the designed curricular which will in turn have a tremendous adverse repercussion on students' academic achievement (Koomson, Akyeampong \& Fobih, 2009).A survey conducted in 2008 by the MoE and the World Bank Monitoring Team revealed that there was misuse of instructional time on the part of head teachers and teachers. Studies have established that mismanagement of time fell below expectations and militated against students' academic achievement (Tamakloe et al. 2011; Koomson et al 2009). As a matter of fact, for effective teaching and learning outcomes, instructional time allotted on the timetable should be judiciously adhered to. This means that all co-curricular activities including sports, excursions, etc should not be made within the instructional time (Ministry of Education, 2001).

\subsection{Statement of the Problem}

In spite of the control measures put in place to check misuse of instructional time in our schools by headmasters and teachers, it appears there are still abuses in the system. The altitudes of some of these stakeholders in education many often than not derail effort made to minimize or not to eradicate the misuse of instruction time in schools. The loss of instructional time generally may be attributed to numerous reasons and amongst these are: public holidays, teachers' absenteeism, maternity and sick leave, etc. These in many ways go against instructional time which in the long run affects students' academic achievement. It is against this background that this study was conducted to examine the misuse of instructional time and its effect on students' academic achievement.

\section{Review of Literature}

\subsection{Instructional Time}

Many schools of thought have propounded that 'time' is an intangible resource and one of the major features of human development. In fact, it is said that time is a non-renewable resource and effective use can be considered to be one of the indicators of the socio-economic development. According to Dowden (2011), time is strictly finite and cannot be increased so one has to look at its use closely. Thus, instructional hours should be used efficiently to enhance both the teaching and learning processes. Woelfel (2010) indicated that social scientists and educational experts find the concept of instructional time to be intellectually unexciting, so commonsensical, and of such obvious importance that it only leads to trivial understanding. Some have dismissed the results on instructional time as an ideology, but not research (McNamara, 2010). Others have argued that when the concept instructional time becomes the basis for creating a variable with which to do research, the measurement issues prove more complex apparently because most scientists conceptualize instructional time as a simple variable (Karweit \& Slavin, 2010; Karweit, 2011).

The amount of time that students spend in public schools varies widely from one country to another. For example, among European countries such as Belgium, France, and Greece, 15-year-old pupils receive an average of more than 1,000 hours per year of total compulsory classroom instruction, while in England, Luxembourg, and Sweden the average is only 750 hours per year. As well, children from the ages 7-8 in England, Greece, France, and Portugal receive an average instructional time of more than 800 hours per year, while in Finland and Norway they receive less than 600 hours. Similar differences among countries exist in the number of classroom lessons per week in different subjects as evident from data from the 2006 Program for International Student Assessment (PISA), a unique international education survey of 15-year-old students conducted by the Organization for Economic Cooperation and Development (OECD) and designed to allow for cross-country comparisons. For instance, these data show that 15-year-old pupils in Denmark receive 4 hours of instruction per week in math and 4.7 hours in language, while pupils of the same age in Austria receive only 2.7 hours of weekly classroom lessons in math and 2.4 hours in language. Overall, total weekly hours of instruction in math, language, and science is 55 percent higher in Denmark (11.5 hours) than in Austria (7.4 hours). Similar magnitudes of disparities in instructional time appear among the Eastern European and Africa that are included in the PISA 2006.

Royelli (2011) and Merrnin (2010) opined that a key educational resource which provides a good foundation to support efforts in improving the quality of teaching and learning in schools is the way time is used as an instructional tool. Indeed, it is long established that time management is unsuitable in the sense that many people cannot really manage time, let alone produce it; for it is a free gift of nature. In this regard, it rests on people to see to its proper management. Berliner (2011) asserted that instructional time should be thought of as a super-ordinate concept and in this way; it is no different from the concept of 'mammal'. Thus, when instructional time is conceived as to a family of concepts, some of it members have not yet achieved the status of concepts in other mature scientific fields. That is, "we do not always have an agreement about the 
meaning of the concept and about the operations by which it can be reliably and validly measured" (Berliner, 2011, p.6). Among the many terms embedded by the super-ordinate concept 'instructional time' include allocated time, engaged time, time-on-task time, academic learning time and waiting time.

According to Jimerson, Woehr, Kaufman and Anderson (2009) Allocated Time usually defined as instructional time as the time that the state, district, school or head teachers provide for instruction. For example, a school may decide that reading and literacy be taught for a period of ninety (90) minutes. Silva (2010) on the other hand, defined Engaged Time as the time that students appear to be paying attention to materials or presentation that have instructional goals. Engaged time is always a subset of allocated time, in fact, a synonym for engaged time is "attention". Baines (2009) also explained Time-on-Task time as an engaged time on a particular learning task. The concept is not synonymous with engaged time, but it is often used as if it were. According to Chmelynski (2009), Academic Learning Time is that part of allocated time in a subject-matter area in which a student is engaged successfully in the activities or with the materials to which he or she is exposed, and in which those activities and material are related to educational outcomes that are valued. Waiting Time, according to Alexander, Entwinsle and Olson (2011) is the time that students must wait to receive some instructional help.

\subsection{Working Hours and Time-Tables of Schools}

Instructional time is the exact or proper use of the periods allotted to teachers to interact with students on topics to be taught or to be learnt on the time table as indicated in teachers' scheme of work and lesson plan for a particular period of time. The implication is that using instructional time more appropriately is not only the appearance of teachers physically in the classroom but also ensuring that topics to be taught and learnt are really taught and learnt (Kim, 2009, Huyvaert, 2008). Nickel, Rice and Tucker (2010) observed that time, as it is, is not a resource that can be replenished. Any bit of it that is lost can never be regained and so organizations, schools and individuals using time should be accountable for it. It is imperative to indicate that the concept of time is defined as the quantity that you measure using clock. This is delineated into seconds, minutes, hours, day, week, month and a year. In Ghana, Senior High Schools (SHSs) run an academic calendar which begins from the month of September and ends July. The duration of the academic year of SHS in the country is forty-five (45) weeks and these have been divided into three terms comprising fourteen weeks appease for first and second terms and seventeen weeks for third term (Ministry of Education Curricular, 2008).

Ministry of Education in collaboration Ghana Education Service provides blank time table to all head of SHS who in turn fill it in such a way as to meet the demands of the locality in which the school is situated. In effect, the GES provides suggestible time periods for each subject per week however, any modification of the official time table needs prior approval from the District Director of Education. Time-tabling in schools should be done by both the headmaster/mistress and the teachers taken into consideration the needs of teaching staff, students as well as the community. The master time table should be conspicuously pasted in the office so as to enable any visitor to see at glance and know what is going on in each of the classroom at any particular point in time with regards to teaching and learning processes (Abadzi, 2010; Attar, 2009; Lewis \& Lockheed, 2009). In the preparation of the time table, subjects which involve practicals such as biology, agricultural science, home economic, etc are given special considerations including the assignment of double periods. In fact, this enables the teachers involved to get enough time to cover both the theory and practical aspects of the subjects. Fisher and Berliner (2007) averred that poor time-tabling could lead to teachers being under-utilized. Indeed, provision of adequate learning time is necessary for effective instruction. Consideration should always be given to the instruction limited time for effective teaching (Lezotte, 1991).

\subsection{Management Techniques of Instructional Time}

Educational authorities have in recent past developed lots of techniques on the effective use of instructional time. Cerdan-Infantes and Vermeersch (2010) argued that time management is an essential feature of a very effective and productive educational system which all educators need to come to terms with. Bray (2006) indicated that successful time management evolves step by step approach with the primary aim of setting priorities in the school. This calls for a decision to be taken and all activities tabulated in order of importance. Every school head needs to prioritize by developing plans both in the short-term and in the long-term. This is because, planning is a managerial process and that the head has to plan the school activities at the beginning of each academic year. Thus, it behooves on the head and his or her subordinates to plan for the daily, weekly and termly activities of the school (Cerdan-Infantes and Vermeersch, 2010; Bray, 2006). In most school situation, the tools for planning are the syllabuses and the scheme of work (Abadzi, 2009). In Ghana, prior to the implementation of the 2007 Educational Reform revised syllabuses were issued to the District Directors of Education for onward distribution to the schools.

The Headmasters' Handbook (2008) makes it mandatory that headmaster/ mistresses are responsible for acquiring the most current syllabuses and are to encourage teachers to use them to prepare their schemes of work for the subjects they teach. As Tamakloe et al (2011) asserted, teaching like any human endeavour demands serious inclusiveness and participation. A well-taught less portrays quality and expertise so every successful teacher plans his or her scheme of work in advance; break the syllabus into teachable units and arrange them logically. Headmasters/mistresses in playing their role should always consult the syllabus to ensure that teachers' scheme of work and the lesson plan conform to each other to facilitate teaching and learning. As a matter of fact, advance preparation should be done by both the head of schools and 
teachers (Smith, 2009). Spodek (2009) opined that "planning begins before students enter school" (p.65). All teaching materials and equipment should be made readily available to the teachers and the headmasters/ mistresses should assist the teachers to get the necessary information for the preparation of teaching materials (Stallings, 2010; Stevens, 2008).

Schools require good leaders to organize the process of teaching and learning to ensure that the mission of the school is achieved (Lydiah and Nasongo, 2009). The core role of the instructional leader is to ensure the achievement of the established mission through creating a good environment for the schools (Lezotte, 2001). For instance, a Kenyan study by Musungu and Nasongo (2008) on the instructional leadership role of secondary school headmasters revealed that headmasters supervised teachers' work by inspecting records such as schemes of work, lesson books, records of work covered, class attendance records, and clock in/ clock out book. This research established that headmasters' frequency of internal supervision contributed towards better performance. This involved proper tuition and revision, thorough supervision of teachers and pupils' work, proper testing policy, syllabus coverage, teacher induction courses and team building. Similar findings have emerged from various Kenyan studies, all which revealed that poor performance in secondary school examinations is a function of poor administration and leadership practices (Ackers \& Hardman, 2001; Githua \& Nyabwa, 2008).

\subsection{Instructional Time Management and Students Academic Achievement}

Given the continued focus on the academic underperformance of public senior high school students in Ghana, policymakers continue to explore interventions to raise such performance. A number of educational leaders often recommend the use of extended learning time as such an intervention. For instance, President Obama's Education Secretary, Duncan expressed support for the use of federal stimulus funds for extended learning time in public schools (Wolfe, 2009). As a matter of fact, many educational reform organizations and policy think tanks have heavily promoted and supported such an option (Farbman \& Kaplan, 2005; Little, Wimer, \& Weiss, 2008; Pennington, 2006; Princiotta \& Fortune, 2009; Rocha, 2007). Using the economic logic of a production process, the more time spent to produce something (holding the other inputs into the production constant) the greater should be the quantity and/ or quality of the output produced. While conventional wisdom may expect a positive relationship between additional hours in the classroom and higher standardized test scores, the scholarly evidence from empirical research on this subject is relatively inconclusive (Farbman \& Kaplan, 2005; Farland, 1998). Employing such reasoning, conventional wisdom among many policymakers is that increasing the time that students spend learning offers a simple and obvious way to improve educational outcomes. However, a search of the previous literature on the relationship between learning time and learning outcomes yielded little research that rigorously tests this conventional wisdom. Previous research did consistently indicate that the more time students spend engaged in learning, the higher the expected levels of academic outcomes (Borg, 1980; Brown \& Saks, 1986; Cotton \& Savard, 1981). Yet, the relationship between just the time allocated to learning and student academic outcomes - without controls for the effective the use of that time remains unclear (Farbman \& Kaplan, 2005). This lack of clarity results from missing or insufficient controls for selection bias and other confounding factors, thereby making causal conclusions from the existing literature on this subject tenuous.

Several recent studies conducted have argued that increase misuse of instructional time negatively affect students' academic achievement (Dobbie \& Fryer, 2011; Farbman \& Kaplan, 2005; Hoxby \& Murarka, 2008). In fact, among scholars, there is consensus that the presence of teachers in the classroom throughout the stipulated instructional time boosts the academic achievement of students. The fact about instructional time is that in almost all educational systems, government mandate a certain number of years and a number of hours per year during which students are required to gain some level of mastery and achievement (Clemens, 2009; Amadio, 2004). More importantly are decisions regarding how instructional time should be distributed in the face of general educational objectives and specific curricular goal (Amadio, 2004). Indeed, it should be made clear that there is a widely held presumption in literature which establishes the impact of instructional time on students' academic achievement (Millot, 2004; Anderson, 2005; Bloom, 2007). Simply put, they found that the more time educational authorities require students to be present in the classroom, the greater the chances of positive time effect on desired learning outcomes (academic achievement).Hansen (2008) reported that more instructional time due to fewer snowrelated school day cancelations and delayed testing increased student performance in Colorado and Maryland. Marcotte and Hemelt (2008) reported that substantial snowfall (leading to fewer days spent at school) is associated with lower pupils' performance in Maryland. Dobbie and Fryer (2011) find that charter schools in New York City that add 25 percent or more instructional time have an annual gain of 0.059 of a standard deviation in math. However, some studies raised doubts about learning effects on instructional time (Demfer, 2007; Katweit, 2009).For instance, Lee and Barro (2001) examined the effect of the amount of time spent in school during the year on student performance across countries while controlling for a variety of measures for school resources, they found no effects of the length of the school year on internationally comparable test scores.

\subsection{Purpose of the Study}

The purpose of this study was in two-folds. First, the study investigated how school heads and teachers public SHS in the Ashanti Mampong Municipality misuse instructional time. Second, the study sought to find out the effect this misuse of instructional time affects students' academic achievement. 


\subsection{Significance of the Study}

The study is aimed at bringing to the fore how instructional time in misused in the teaching and learning process. It is therefore envisaged that the findings of this study will unearth the factors that bring about instructional time mismanagement. This will afford the Ministry of Education and for that matter Ghana Education Service the opportunity to address this unfortunate situation. Also, this study will expose headmasters/ mistresses, teachers, parents and all stakeholders in education to how misuse of instructional time affect students' academic achievement. This, in fact, will go a long way to inform school heads to sit up and ensure that instructional time is effectively used to foster students' academic achievement.

\subsection{Research Questions}

- What are the factors that account for misuse of instructional time?

- What are the challenges that Headmasters/ mistresses face in the management of instructional time?

- What is the relationship between management leadership techniques and misuse of instructional time?

- What is the relationship between actual instructional time teachers' spent with students and students' academic achievement?

\subsection{Hypothesis}

- Ho There is a direct and negative relationship between misuse of instructional time and students' academic achievement.

\section{Methodology}

\subsection{Design of the Study}

Descriptive survey design was the research design used for the study. This design was considered appropriate because as Denzin and Lincoln (2000) put it "descriptive survey is oriented towards the explanation and description of the status of a given phenomenon rather than towards the isolation of causative factors" (p.120). In this study, the mismanagement of instructional time in Senior High Schools was assessed.

\subsection{Population and Sampling Procedures}

The population of this study comprised all headmasters/ mistress and teachers of the four public Senior High Schools in the Ashanti Mampong Municipality of Ghana. These four Public Senior High Schools include Amaniampong SHS, St. Monicas SHS, St. Joseph SHS and Kofiase STHS. Purposive sampling techniques was therefore used to select all the four (4) headmasters/mistress and three hundred and twenty-two (322) teachers in the Public Senior High Schools in the Ashanti Mampong Municipality. The population hence was three hundred and twenty-six (326).

\subsection{Research Instrument}

Questionnaire was the main data collection instrument. Questionnaires were used because they are the main method of data collection and also the population was literate. Also the coverage of questionnaire is wide as researchers can reach respondents more easily and is unaffected by problems of 'non-contacts'. Again, the popularity of questionnaires is probably based on some advantages among which are its low cost in terms of both money and time involved (Sarantakos, 1997). In all 25 items made up the questionnaire of which 5 items were open-ended questions and the remainder close-ended ones.

\subsection{Data Analysis Plan}

All the research questions were answered using Pearson zero-order correlation matrix. However, the hypothesis of the study was tested by means of multiple regression procedures.

\section{Results and Discussions}

Research questions one and two were answered via multiple regression procedures while research questions three and four as well as the hypothesis were answered and test using Pearson correlation matrix.

- Research Question 1: What are the factors that account for misuse of instructional time?

This research question of the study sought to establish the factors that bring about misuse of instructional time. To accomplish this, multiple regression procedures were used to ascertain which of the factors identified explain the misuse of instructional time. The results of the multiple regression analysis between the factors and misuse of instruction time are presented in 


\begin{tabular}{|c|c|}
\hline Predictors B & $\begin{array}{c}\text { Instructional Time Misuse } \\
\text { Model Summary }\end{array}$ \\
\hline Public Holidays & $.055(.086)$ \\
\hline Maternity Leave & $.533(.026)^{*}$ \\
\hline Sick Leave & $.491(.014)^{*}$ \\
\hline Absenteeism & $.624(.020)^{*}$ \\
\hline Lateness & $.392(.019)^{*}$ \\
\hline Teachers Apathy & $.392(.019)^{*}$ \\
\hline Constant & $.216(.022)$ \\
\hline $\mathrm{R}$ & 3.750 \\
\hline $\mathrm{R}^{2}$ & .678 \\
\hline $\mathrm{AR}^{2}$ & .640 \\
\hline
\end{tabular}

Table 1: The Factors That Account for Misuse of Instructional Time

$$
{ }^{*} p<0.05
$$

Table 1reveals the results of the multiple regression analysis. The Model summary gives the coefficients of the independent variables, the standard error, the level of significance, the correlation $(R)$, the $R^{2}$ and the adjusted $R^{2}$. The findings from the Table establish maternity leave, sick leave, absenteeism, lateness and teachers' apathy as the predictors of instructional time misuse.

The findings of current study corroborate studies done by a number of researchers

- Research Question 2: What are the challenges that Headmasters/ mistresses face in the management of instructional

time?

Research question two of the study wanted to establish the challenges that Headmasters/ mistresses face in the management of instructional time. In this regard, multiple regression procedures were used to ascertain the challenges that face management of instructional time. Table 2 presents the results of the multiple regression analysis.

\begin{tabular}{|c|c|}
\hline Predictors B & $\begin{array}{c}\text { Challenges of Instructional Time Usage } \\
\text { Model Summary }\end{array}$ \\
\hline Apathy Towards Bells & $.493(.018)^{*}$ \\
\hline Classes of Absentee Teachers & $.355(.016)^{*}$ \\
\hline Teachers Supervision & $.470(.019)^{*}$ \\
\hline Staff Meetings & $.363(.021)^{*}$ \\
\hline Co-curricular Activities e.g. Sports & $.522(.019)^{*}$ \\
\hline Teachers Apathy & $.315(.026)^{*}$ \\
\hline Constant & 2.970 \\
\hline $\mathrm{R}$ & .840 \\
\hline $\mathrm{R}^{2}$ & .619 \\
\hline $\mathrm{AR}^{2}$ & .610 \\
\hline
\end{tabular}

Table 2: The Challenges That Headmasters/ Mistresses Face in the

Management of Instructional Time Usage

$$
{ }^{*} p<0.05
$$

The results in Table 2 depict the multiple regression analysis. The Model summary gives the coefficients of the independent variables, the standard error, the level of significance, the correlation $(\mathrm{R})$, the $\mathrm{R}^{2}$ and the adjusted $\mathrm{R}^{2}$.From the Table, it is evidently clear that all the independent variables, thus apathy towards bells, classes of absentee teachers, teachers' supervision, staff meetings, co-curricular activities and teachers' apathy were significant predictors of the challenges of instructional time usage.

- Research 3: What is the relationship between management leadership techniques and misuse of instructional time?

Every aspect of instructional programme of a school depends on the effective management of teachers and students in the school. Research question three sought to establish the relationship between management leadership technique and misuse of instructional time. To accomplish this, Zero-order correlation was used to ascertain the relationship between management leadership technique and misuse of instructional time. The results can be found in Table 3. 


\begin{tabular}{|c|c|}
\hline & Instructional Time Misuse \\
\hline Management/ Leadership Techniques Pearson Correlation & $0.645^{* *}$ \\
\hline Sig. (2-tailed) & .000 \\
\hline $\mathrm{N}$ & 326 \\
\hline
\end{tabular}

Table 3: Relationship between Management Leadership Techniques and Misuse of Instructional Time **. Correlation Is Significant at the 0.01 Level (2-Tailed)

The Zero-order correlation coefficients obtained between management leadership technique and misuse of instructional time is $r=0.645^{* *}$. This is positive with significance or $\mathrm{p}$-value $=0.000$ which is less than alpha $=0.01$. The findings therefore submit that management leadership technique was significantly related to instructional time misuse.

Findings of this current study uphold views shared by a number of research works such as Cerdan- Infantes and Vermeersch (2010), Bray (2006) and Abadzi(2009). In fact, according to Tamakloe et al (2011), teaching like any human endeavour demands serious inclusiveness and participation. Thus, Schools require good leadership style to organize the process of teaching and learning to ensure that the mission of the school is achieved (Lydiah and Nasongo, 2009).For instance, a Kenyan study by Musungu and Nasongo (2008) on the instructional leadership role of secondary school headmasters revealed that headmasters supervised teachers' work by inspecting records such as schemes of work, lesson books, records of work covered, class attendance records, and clock in/ clock out book contributed towards judicious use of instructional time and better performance. However, similar findings have opined that misuse of instructional time and poor performance in secondary school examinations is a function of poor administration and leadership practices/ techniques (Ackers \& Hardman, 2001; Githua \& Nyabwa, 2008). This therefore suggests that teaching materials and equipment should be made readily available to the teachers and that headmasters/ mistresses should assist the teachers to get the necessary information that will facilitate the teaching and learning process.

- Research 4: What is the relationship between actual instructional time teachers' spent with students and students' academic achievement?

Time management is an essential feature of a very effective and productive educational system which all educators need to come to terms with. The interest in this research question was to establish the extent to whichthe actual instructional time teachers' spend with students relates to the students' academic achievement. Zero-order correlation was used to ascertain the extent of the relationship. Table 4 presents the summary of the results.

\begin{tabular}{|c|c|}
\hline & Students' Academic Achievement \\
\hline Actual Instructional Time Spent Pearson Correlation & 0.748 \\
\hline Sig. (2-tailed) & .000 \\
\hline $\mathrm{N}$ & 326 \\
\hline
\end{tabular}

Table 4: Relationship between Actual Instructional Time Teachers' Spent with Students and Students' Academic Achievement **. Correlation Is Significant at the 0.01 Level (2-Tailed)

According to results in Table 4, the Zero-order correlation coefficients established between actual instructional time spent and students' academic achievement is $r=0.748^{* *}$. This is positive with significance or $p$-value $=0.000$ which is less than alpha $=0.01$. This shows that actual instructional time spent was significantly related to students' academic achievement. Findings from this study are consistent with a plethora of studies(Borg, 1980; Brown \& Saks, 1986; Cotton \& Savard, 1981).However, the relationship between just the time allocated to learning and student academic outcomes - without controls for the effective the use of that time - remains unclear (Farbman \& Kaplan, 2005). This current study corroborates the works of Hansen (2008). He reported that more instructional time due to fewer snow-related school day cancelations and delayed testing increased student performance in Colorado and Maryland. Marcotte and Hemelt (2008) confirmed this in their study and asserted that substantial snowfall (leading to fewer days spent at school) is associated with lower pupils' performance in Maryland. Dobbie and Fryer (2011) concluded that charter schools in New York City that add 25 percent or more instructional time have an annual gain of 0.059 of a standard deviation in math. Notwithstanding this, the findings of this study are not consistent with studies done by Demfer, (2007) and Katweit (2009).

\subsection{Testing the Hypothesis}

Efforts were made to test the hypothesis that guided the study. In this regard, multiple regression procedures were used to test the hypothesis. The null hypothesis therefore states that... 
$\mathrm{H}_{0}$ There is a direct and negative relationship between misuse of instructional time and students' academic achievement. The results of the Zero-order correlation between misuse of instructional time spent and students' academic achievement is shown in Table 5.

\begin{tabular}{|c|c|}
\hline & Students' Academic Achievement \\
\hline Misuse of Instructional Time Pearson Correlation- & 0.835 \\
\hline Sig. (2-tailed) & .000 \\
\hline $\mathrm{N}$ & 326 \\
\hline
\end{tabular}

Table 5: The Relationship between Misuse of Instructional Time and

Students' Academic Achievement

**. Correlation Is Significant at the 0.01 Level (2-Tailed)

The relationship between misuse of instructional time and students' academic achievement as presented in Table 5 shows that the Zero-order correlation coefficients obtained is $r=-0.835^{* *}$. This is positive with significance or $p$-value $=0.000$ which is less than alpha $=0.01$ implying that instructional time misuse and students' academic achievement was significantly related.

Several recent studies including this present findings have argued that increase misuse of instructional time negatively affect students' academic achievement (Dobbie \& Fryer, 2011; Farbman \& Kaplan, 2005; Hoxby \& Murarka, 2008). Indeed, there is a widely held presumption in literature which establishes the impact of misuse instructional time on students' academic achievement (Millot, 2004; Anderson, 2005; Bloom, 2007). Simply put, studies have found that the more educational authorities misuse instructional time the greater the chances of negatively affecting students' desired learning outcomes (academic achievement).

Hence, with reference to the findings of this study and lots of literature in support, we failed to reject the hypothesis that guided this study, thus "there is a direct and negative relationship between misuse of instructional time and students' academic achievement".

\section{Conclusion}

In this study, an attempt was made to find out the extent to which the academic performance of the students was affected by instructional time misuse. The study therefore established that factors such as maternity leave, sick leave, absenteeism and lateness contribute immensely to the misuse of instructional time hence their telling effect on students' academic performance. The study further ascertained that certain constraints which include apathy towards bells, classes of absentee teachers, teachers' supervision, staff meetings, co-curricular activities and teachers' apathy militate against headmaster/ headmistress effective usage of instructional time. This presupposes that the students' academic performance was strongly moderated by these factors and challenges. The researcher therefore concludes that when these variables are high, thus their prevalence rate there is the likelihood that students' academic performance will be adversely affected. This therefore suggests that headmasters/ mistresses and stakeholders in the educational sector at large should put pragmatic measures in place to see to the efficient and effective use of instructional time to foster and enhance the academic performance of students. Likewise, the researcher concludes that lateness and absenteeism on the part of teachers and students have a telling effect on students' academic performance. On the basis of the findings and conclusions discussed above, the following recommendations are made.

\section{Recommendations}

On the basis of the findings and conclusions discussed on this current study, the following recommendations are made.

- In this study, misuse of instruction time was found to have a negative effect on students' academic achievement public senior high schools. It is therefore recommended the Government, the Ministry of Education and stakeholders in education should ensure the efficient and effective usage of instructional time at the Senior High Schools to be specific.

- Also, the current study established a positive association between management style and/ or leadership technique and instructional time usage. It is hence recommended that headmasters/headmistresses should be exposed to appropriate management style and leadership technique to see to the judicious utilization of instructional time.

\section{References}

i. Abadzi, H. (2010). Efficient learning for the poor: insight from the frontier of cognitive neuroscience. Washington, DC: World Bank.

ii. Amadio, M. (2004). Primary education: length of studies and instructional time. Educational Innovationand Information. 92, 2-7 
iii. Attar, M. (2009). Ghana country report; strategies for introducing new curricular in West Africa-Pillai S., ed. Geneva: IBE-UNESCO

iv. Baines, L. (2009). Learning from the world: Achieving more by doing less Phi Delta Kappan 10(7), 98-100

v. Berliner, D. C. (2012). What's all the fuss about instructional time? New and London: Teachers College Press

vi. Bloom, B. (2007). Handbook on formative and summative evaluation of student learning. New York: McGraw Hill

vii. Borg, W. R. (1980). Time and School Learning. In C. Denham \& A. Lieberman (Eds.), Time to Learn. Washington, D. C.: National Institute of Education.

viii. Brown, B. W., \& Saks, D. H. (1986). Measuring the Effects of Instructional Time on Student Learning: Evidence from the Beginning Teacher Evaluation Study. American Journal of Education, 94, 480-500.

ix. Bray, M. (2011). Double-shift schooling: design and operation for cost-effectiveness (2nd ed.). London: The Commonwealth Secretariat and IIEP-UNESCO

x. Chmclynski, C. (2009). Extend school day and year for NCLB? Education Digest, 25, 41-44

xi. Cotton, K., \& Savard, W. G. (1981). Time Factors in Learning. Portland, OR: Northwest Regional Educational Laboratory.

xii. Dowden, B. (2011). Time. In James Fieser, Ph.D., Bradley Dowden. Ph. D. The internet encyclopedia of philosophy. New York: Simon \& Schuster

xiii. Farbman, D., \& Kaplan, C. (2005). Time for a Change: The Promise of Extended-Time Schools for Promoting Student Achievement. Retrieved from http:/ / www.mass2020.org/ files/ file/ Time-for-a-change(1).pdf .

xiv. Farland, G. (1998). Extended Learning and Year-Round Programs: An Overview. Retrieved from http:/ / cehd.umn.edu/ CAREI/ Reports/ docs/ extended1995.rtf .

xv. Fisher, C. W, \& Berliner, D. C. (2007). Perspective on instructional time. New York: Longman

xvi. Hindle, T. (2009). Manage your time. London: Darling Kindersley

xvii. Huyvaert, S. H. (2008). Time is of essence: learning in schools. Needham Heights, MA: Allyn \&

xviii. Karweit, N. L., \& Slavin, R. E. (1982). Time-on-task: Issues of timing, sampling and definition. Journal of Educational Psychology. 74, 844-851

xix. Kaeweit, N. L. (2009). Time on task: A research review. Baltimore, MD: The John Hopkins University, Center for Social Organization of School

xx. Koomson, A., Akyeampong, K., \& Fobih, D. (2009). Management of instructional time in some Ghanaian public primary school. Journal of Educational Management, 2, 30-41

xxi. Lewis, M., \& Lockheed, A. (2009). Beneath Education Production Functions: The case of Primary Education in Jamaica. Peabody Journal Education. 80(1), 6-28

xxii. Lezotte, L. (1991). Correlates of effective schools: the first and second generation.Okemos, MI: Effective Schools Products, Ltd.

xxiii. Little, P. M., Wimer, C., \& Weiss, H. B. (2008). After School Programs in the 21st Century: Their Potential and What It Takes to Achieve It. Retrieved from http://www.hfrp.org/publications-resources/ browse-ourpublications/after-school- programs-in-the-21st-century-their-potential-and-what-it-takes-to-achieve-it.

xxiv. Lydiah, L. M. \& Nasongo, J. W. (2009). Role of the head teacher in academic achievement in secondary schools in Vihiga District, Kenya. Current Research Journal of Social $\quad$ Sciences 1(3), 84-92, Available online athttp:/ / maxwellsci.com/ print/ crjss/ (3)84-92.pdf

xxv. McNamara, D. R. (1981). Attention, time-on-task and children's learning: Research or Ideology? Journal of Education for Teaching. 7, 284-297.

xxvi. Millet, B. (2004). Economics of educational time and learning (Pp. 354-358). In International Encyclopedia of economics of education. Oxford: Pergamon-Elsevier

xxvii. Ministry of Education (2001). Circular on co-curricular activities in the schools. Accra: Ghana Publishing Company

xxviii. $\quad$ Mirmin, N. D. (2010). It's about time. Princeton. N.I.: Princeton University Press

xxix. Musungu, L. L. \& Nasongo, J. W. (2008). The head-teacher's instructional role in academic achievement in secondary schools in Vihiga district, Kenya. Educational Research and Review, 3(10), 316-323, Available online at http:/ / www.academicjournals.org/ ERR

xxx. Nickel, P., Rice, T., \& Tucker, C. (2010). The time dimension: an interdisciplinary guide. New

xxxi. Pennington, H. (2006). Expanding Learning Time In High Schools. http:/ / www.americanprogress.org/ issues/ 2006/ 10/ pdf/ extended_learning_report.pdf.

xxxii. Princiotta, D., \& Fortune, A. (2009). The Quality Imperative: A State Guide to Achieving the
Extended $\quad$ Learning

York: Praeger Retrieved from

Promise of http:/ / www.ccsso.org/ Resources/ Publications/ The_Quality_Imperative_A_State_Guide_ Achieving_the_Promise_of Extended_Learning_Opportunities_html.

xxxiii. Royelìi, J. (2009). Does School Quality Expläin the Recent Black/ White Trend? Journal of Labor Economics. 14, 231-253

xxxiv. Silva, T. (2008). On the clock: Rethinking the way schools liselillie. Washington. D. C.: $\quad$ Education Section 
xxxv. Smith, B. (2009). Quality Matters: Annual Instructional Time in an Urban School System. Educational Administration Quarterly. 36(5), 652-682

xxxvi. Spodek, B. (2009). Today's kindergarten. New York: Teachers College Press

xxxvii. Stalling, J. (2010). Results of Classroom Observation in Tunisia, Morocco, Ghana and Brazil. at the Annual Meeting of the American Educational Research Association: San Francisco, California.

xxxviii. Tamakloe, E. Z., Ameda he, F. K. \& Atta E. T. (2011). Principle and methods of teaching. Accra: Black Mask Ltd. xxxix. Woelfel, K. (2005). Learning takes time for at-risk learners. Principal (1), 18-21 